in Goudie, Andrew S., Editor in Chief, Encyclopedia

of Global Change, 2 vols (Oxford: Oxford University

Press, 2002), vol. 1, pp. 399-401.

\title{
Environmental Bioethics
}

Environmental bioethics, or environmental ethics, is the theory and practice relating to values in and duties to, or concerning, the natural world. This involves an environmental philosophy, or philosophy of nature. A recurrent issue is whether ethics is applied to the environment analogously to its application in business, medicine, engineering, law, and technology; or whether it is more radical, revising traditional ideas about what is of moral concern. The applied ethic is anthropocentric, the central concern is whether humans are helped or hurt by the condition of their environment.

A naturalistic ethics is more radical, holding that animals, plants, endangered species, ecosystems, and even the Earth as a whole ought to be the direct objects of moral concern, at times at least. Others than humans also count morally-whales who are slaughtered, or ancient forests, or Earth as a biotic community disrupted by humanintroduced global changes. If so, environ- 
mental bioethics differs from bioethics more generally, which has previously been largely medical, with human health and welfare its concern. Environmental ethics is unique in moving outside the sector of human interests.

Philosophers have formed philosophies of nature for millennia, although in the West the meaning of human life has usually been their main focus. Environmental ethics and philosophy arose in the second half of the twentieth century. The impetus came from a dramatically escalating power of humans to affect nature, associated with, for example, the loss of species or global warming. Industrialization, advanced technologies, global capitalism, consumerism, ecological and evolutionary sciences, and exploding populations have all contributed to a concern that humans are not now in a sustainable relationship with their natural environment. Nor have they distributed the benefits derived from natural resources equitably, nor have they been sensitive enough to the welfare of the many other species.

A parallel concern for animal welfare also arose, sometimes advocating animal rights. These ethicists typically cared for domestic animals, such as food animals or pets, but they also took wild animals into consideration. They found common interests with environmentalists, but also many divisions. One may be vegetarian, while the other approves of hunting. An animal welfare ethics seeks to be "humane"; an ecocentric ethics has more concern for ecosystems, soil and water conservation, or wilderness preservation. The American forester Aldo Leopold termed this a land ethic, where "land" is the regional biotic community of life. [See the biography of Leopold.]

Biocentrism is sometimes used as a general synonym for any naturalistic or nonanthropocentric ethics. Biocentrism refers more specifically to an ethics of respect for life, focused on organisms or individuals. In contrast to an animal welfare ethics, biocentrism holds that any living thing can count morally, although plants, insects, animals, and humans need not count equally. Animals and plants can and must use each other as resources, which justifies some human uses of the environment. But human uses can be unjustified, failing to consider the worth, or intrinsic value, of living things-cutting old- growth forests, for example, instead of recycling or using tree plantations to meet needs for paper and wood.

Axiological environmental ethics identifies various values carried by nature. Humans value nature as their lifesupport system, economically, recreationally, scientifically, aesthetically, for genetic diversity, as cultural symbol, religiously, and so on. Such values may be assigned to natural things by humans, or they may come into existence in human interactions with nature. Further, many values are found in nature that are present there independently of human valuations-autonomously intrinsic values. Such values are discovered, not placed.
Plants and animals alike defend their own lives; they are members of species lineages perpetuated over millennia. Ecosystems are the sources and systems of life, having generated numerous species over evolutionary time. An adequate ethics will need to optimize all relevant values, humanistic and naturalistic. Moral concern needs to focus on the relevant survival unit, not always the individual, often the species, the ecosystem, or, ultimately, the planet Earth.

Some values carried by nature are said to be "subjective," meaning that they are found only in the experiences of psychological subjects resulting from their interactions with the world, as contrasted with "objective," meaning present in the world independently of such experiences in subjects, particularly those of humans. No one denies that humans enjoy such experiences of value. The issue is whether, apart from humans, animals and plants embody any values on their own, and whether these too can and ought to figure in environmental ethics (animal pain, the flourishing of a sequoia tree, or an endangered insect species). Some, invoking sentient environmental ethics, think that the higher animals (vertebrates, mammals) with developed central nervous systems are capable of such valuing experiences (subjects), but that lower animals and plants are not, much less other mere objects, such as mountains or rivers. All the latter have no values of their own.

Deep ecology emphasizes the ways in which humans, although individual selves, ought to extend their selves through a web of connections, taking a model from ecology where living things are what they are in their environments. In this view, humans have such entwined destinies with the natural world that their richest quality of life involves a larger identification with the communities, human and natural, by which they are surrounded. Such transformation of the personal self will result in an appropriate care for the environment.

Human ecology or social ecology taken as an environmental ethics argues that the focus needs to be on the institutions of society, its politics, business, development plans, population policies, legal systems, patterns of resource distribution, and so on. What is needed is not some revised metaphysics of nature so much as criticism and reformation of human patterns of social behavior regarding nature. Although these follow from the worldviews of individuals, an environmental ethics must be corporate, because action must be taken in concert. Accordingly, an environmental policy, a political ecology, a green politics is especially needed. Bioregionalism argues that such human-nature relationships can best be worked out at regional levels - as in the United States Southwest, or the Scandinavian Arctic. Bioregionally, people can retain a strong sense of place; government, business, lifestyles, and environmental integrity can be kept in a coherent regional whole. 
Since the United Nations Conference on Environment and Development (UNCED) at Rio de Janeiro in 1992, much interest has gathered under the umbrella of sustainable development ethics. Developing nations argued that environmental conservation could not and should not be separated from development, which involved environmental justice as much as environmental preservation. About fourfifths of the world's population, including most nations, produce and consume only about one-fifth of the world's goods. About one-fifth of the world's population (the Group of Seven [leading industrial] nations and a few others) produce and consume four-fifths of the goods. That, they say, is neither fair nor sustainable. Consumption by the rich is more of a problem than increasing population in the developing nations. The global warming threat is produced by industrial nations, not developing ones. They call for an ethics of ecojustice.

Sustainable development, however, has proved a rather elastic concept, sometimes meaning sustainable growth, or profit, or resource base, or sustainable opportunity, or sustainable communities. Those inclined to a more ecological ethics argue that ultimately humans ought to have a sustainable biosphere ethics (which global climate change might seriously threaten).

An ecofeminist ethics finds an alliance between the forces that exploit nature and those that exploit $\mathrm{w}$ omen, often also finding a care for nature present among women, contrasting with an attitude of dominion among men. Such patriarchal bias has been present in many societies but has especially characterized the modem West.

Attitudes toward nature include religious convictions, and many argue that a religious environmental ethics must be part of the answer; indeed it is essential to an answer, since religion, globally, is more influential than philosophy; and religion, misunderstood, has helped cause the crisis. Monotheistic religions, such as Christianity, Judaism, and Islam, urge an ethics of the stewardship of creation; or they may prefer to speak of caring for a sacred creation, or reverence for life. A creation spirituality has a strong sense of the divine presence in nature. Others argue that Eastern religions have something to offer, such as the yang and yin of Taoism in harmonious balance, or the ahimsa, noninjury and respect-for-life traditions in Hinduism and Buddhism. Native Americans and indigenous peoples in Africa, Australia, and South America have claimed that their traditions respect the natural world better than the modern West.

A postmodern environmental ethics doubts whether humans can know nature independently of the various cultural schemes used to interpret nature, plural as these are. A worldview is a social construction more than a realist account of nature as it is in itself. These views can be better or worse (judged by their sustainability, or eq- uitable distribution of resources, or quality of life), and that is all that is needed for an environmental ethics, which is. after all, about relating persons to places: art ethics of place. Such environmental ethics may differ between various peoples: a pluralist environinental ethics. A communitarian ethics locates humans in both human and biotic communities, with values and duties at multiple levels and scales. These ethics may join, however, as all humans see themselves as Earthlings, with their home planet as a responsibility.

[See also Belief Systems; Conservation; Environmental Law; Gaia Hypothesis; Human Impacts, article on Human Impacts on Biota; Policy Analysis; and Valuation.]

\section{INTERNET RESOURCE}

An extensive Web site bibliography is at http://www.cep.unt.edu/ ISEE.html/. This site also includes the International Society for Environmental Ethics Newsletter, updating the current bibliographic literature on a quarterly basis.

\section{B I B L I O G R A P H Y}

Attfield, R. The Ethics of Environmental. Concern. 2d ed. Athens: University of Georgia Press, 1993

Callicott, J. B. In Defense of the Land Ethic. Albany: State University of New York (SUNY) Press, 1989.

----- Earth's Insights: A Survey of Ecological Ethics from the Mediterranean Basin to the Australian Outback. Berkeley: University of California Press, 1994.

Devall, B., and G. Sessions. Deep Ecology. Salt Lake City, Utah: Peregrine Smith Publishers, 1985.

Elliot, R. ed. Environmental Ethics. New York: Oxford University Press, 1995.

Gruen, L., and D. Jamieson, eds. Reflecting on Nature: Readings in Environmental Philosophy. New York: Oxford University Press, 1994.

Johnson, L. A Morally Deep World: An Essay on Moral Significance and Environmental Ethics. Cambridge: Cambridge University Press, 1991.

Norton, B. G. Toward Unity Among Environmentalists. New York: Oxford University Press, 1991.

Regan, T., ed. Earthbound: New Introductory Essays in Environmental Ethics. New York: Random House, 1990.

Rolston, H. Environmental Ethics: Values in and Duties to the

Natural World. Philadelphia: Temple University Press, 1987.

Conserving Natural Value. New York: Columbia University Press. 1994.

Taylor. P Respect for Nature. Princeton, N.J.: Princeton University Press, 1986.

- HOLMES Rolston III 